\title{
IMPLEMENTASI METODE CERTAINTY FACTOR PADA SISTEM PAKAR DIAGNOSIS PENYAKIT IKAN KOI BERBASIS WEB
}

\author{
Rizal Fikri, Sentot Achmadi, Nurlaily Vendyansyah \\ Program Studi Teknik Informatika S1, Fakultas Teknologi Industri \\ Institut Teknologi Nasional Malang, Jalan Raya Karanglo km 2 Malang, Indonesia \\ fikrier97.rf@gmail.com
}

\begin{abstract}
ABSTRAK
Ikan koi merupakan salah satu ikan hias yang banyak digemari masyarakat dan berbagai kalangan karena warna serta corak yang sangat indah. Ikan koi sampai saat ini masih menjadi ladang bisnis yang menjanjikan dalam bidang perikanan. Kegiatan budidaya ikan koi merupakan kegiatan yang mempunyai resiko besar untuk pembudidaya karena ikan koi merupakan ikan yang rentan terserang penyakit dan mengakibatkan kematian. Serangan penyakit pada ikan koi merupakan masalah yang sering dihadapi oleh pembudidaya ikan. Dengan banyaknya penyakit yang mempunyai gejala yang hampir sama tersebut membuat pembudidaya sulit mendiagnosis penyakit pada ikan koi. Permasalahan tersebut bisa dipecahkan dengan metode Certainty Factor yaitu metode yang digunakan untuk mencari nilai kepastian dan ketidak pastian suatu gejala pada penyakit. Pada penelitian ini menggunakan mesin inferensi forward chaining sebagai metode penelusuran yang dituangkan dalam sistem pakar berbasis web yang dibangun dengan bahasa pemrograman php, dan database MySQL. Data penelitian diperoleh dari Dinas Perikanan Kota Blitar. Dari 50 pengujian aplikasi sistem pakar didapatkan hasil diagnosis sistem dengan diagnosis pakar 46 hasil tepat, dan 4 hasil tidak tepat, hasil presentase keakurasian sistem dengan pakar sebesar $92 \%$. Hasil diagnosis berupa data penyakit berdasarkan gejala yang telah dipilih, kemungkinan penyakit lain, nilai presentase keyakinan diagnosis penyakit tersebut dan menampilkan langkahlangkah penanganan serta cara pencegahan.
\end{abstract}

Kata Kunci : Certainty Factor, Diagnosis Penyakit, Ikan Koi, Sistem Pakar

\section{PENDAHULUAN}

Ikan koi merupakan salah satu ikan hias yang banyak digemari masyarakat dan berbagai kalangan karena warna serta corak yang sangat indah. Ikan koi sampai saat ini masih menjadi ladang bisnis yang menjanjikan dalam bidang perikanan. Ikan koi hidup di daerah beriklim sedang pada perairan air tawar. Ikan ini cenderung tumbuh cepat, pada tahun pertama dapat tumbuh hingga ukuran $30 \mathrm{~cm}$ dan bisa mencapai ukuran $50 \mathrm{~cm}$. Pertumbuhan ikan koi bisa lebih cepat atau lambat tergantung pada banyak hal antara lain kualitas air kolam, kedalaman kolam, makanan, dan padatnya komunitas ikan pada kolam [1]

Kegiatan budidaya ikan koi merupakan kegiatan yang mempunyai resiko besar untuk pembudidaya karena ikan koi merupakan ikan yang rentan terserang penyakit dan mengakibatkan kematian. Penanganan penyakit pada ikan koi tidak semua sama. Penanganan dapat dilakukan setelah jenis penyakit diketahui. Penyakit ikan koi umumnya memiliki gejala umum yang hampir sama. Dengan banyaknya penyakit yang mempunyai gejala yang hampir sama tersebut membuat petani ikan sulit mendiagnosis penyakit pada ikan koi.

untuk mengurangi kesalahan diagnosis tersebut dibutuhkan sebuah sistem terkomputerisasi sistem pakar diagnosis penyakit ikan koi berbasis web. Metode yang digunakan adalah Certainty Factor, Metode Certainty Factor digunakan untuk menyatakan seberapa akurat, atau dapat diandalkan dalam menilai suatu predikat. Certainty factor menggunakan nilai untuk mengasumsikan derajat keyakinan seorang pakar terhadap suatu data.

\section{TINJAUAN PUSTAKA}

\subsection{Penelitian Terdahulu}

Mariana (2019) melakukan penelitian tentang diagnosis penyakit tanaman semangka. Permasalahan yang terjadi adalah kerusakan tanaman semangka yang diakibatkan oleh penyakit tanaman semangka. Kurangnya akan pengetahuan tentang penyakitpenyakit tanaman semangka menjadi salah satu penyebabnya. Oleh sebab itu sistem pakar dibangun untuk memberikan solusi kepada masyarakat terkait pengenalian penyakit tanaman semangka [2]

Saputra (2019) menggunakan sistem pakar untuk diagnosis penyakit pencernaan. Dengan adanya sistem pakar ini, diharapkan dapat membantu para pengguna dalam mendiagnosis penyakit pencernaan yang dialami. Hasil Pengujian sistem aplikasi sistem pakar diagnosis penyakit pencernaan pada manusia berbasis web menggunakan metode Certainty Factor fungsional berjalan dengan baik [3]

Sinaga, dkk (2018) Melakukan penelitian dimana pekermbangan teknologi membuat teknologi dibidang smartphone berlomba dalam membuat produk terbaru. Sehingga teknologi smartphone sekarang ini membuat smartphone rentan terhadap kerusakan. Melihat permasalahan tersebut penulis 
membuat sistem pakar mendiagnosis kerusakan smartphone android. Adapun metode yang digunakan pada sistem pakar ini adalah Metode Certanty Factor. [4]

Putri (2018) pada penelitian yang berjudul sistem pakar diagnosis penyakit campak roseola. Diagnosis dini penyakit roseola merupakan cara baik untuk menghindari akibat yang buruk bagi kesehatan bayi. Sistem Pakar penyakit Roseola mampu membantu masyarakat ekonomi rendah untuk mendiagnosis sendiri penyakit tersebut. Pengolahan gejala-gejala berdasarkan fakta dengan nilai dan perhitungan metode Certainty Factor. Certainty Factor menetukan hasil yang baik dengan pengkombinasian nilai pakar dan nilai user. [5]

Wahyuningsih (2021) melakukan penelitian diagnosis penyakit campak rubella, memiliki kelebihan dapat diakses dan digunakan dimana saja menggunakan koneksi internet. Metodologi yang digunakan untuk mendiagnosis penyakit campak rubella pada penelitian ini adalah menggunakan metode Certainty Factor (CF). [6]

\subsection{Sistem Pakar}

Sistem pakar adalah suatu sistem komputer yang bisa menyamai atau meniru kemampuan seorang pakar. Pakar yang dimaksud disini ialah orang yang mempunyai keahlian khusus yang dapat menyelesaikan masalah yang tidak dapat diselesaikan orang awam. Sistem pakar adalah suatu sistem komputer yang menyamai (emulates) kemampuan pengambilan keputusan dari seorang pakar-pakar. Basis pengetahuan yang diperoleh, diambil dari pengalaman seorang pakar maupun teori-teori yang ada pada bidang yang spesifik saja, oleh karena itu sistem pakar memiliki keterbatasan [7]

\subsection{Forward Chaining}

forward chaining merupakan strategi pencarian yang memulai proses pencarian dari sekumpulan data atau fakta, dari data-data tersebut dicari suatu kesimpulan yang menjadi solusi dari permasalahan yang dihadapi. Mesin inferensi mencari kaidahkaidah dalam basis pengetahuan yang premisnya sesuai dengan data-data tersebut, kemudian dari kaidah-kaidah tersebut diperoleh suatu kesimpulan. Runut maju memulai proses pencarian dengan data data driven [8]. Proses mesin inferensi forward chaining dapat ditunjukkan pada gambar 1 .

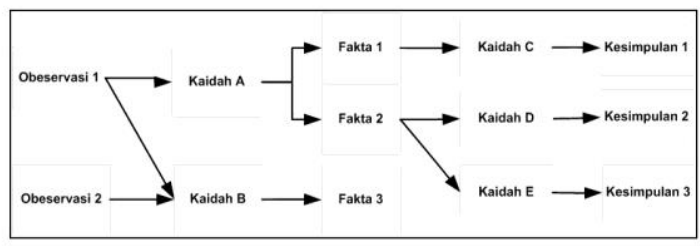

Gambar 1. Forward chaining

\subsection{Metode Certainty Factor}

Certainty Factor merupakan metode untuk menampung pernyataan-pernyataan dari seorang ahli dalam penyampaiannya. Hasil analisis mendeskripsikan tingkat kepercayaan ahli terhadap masalah yang dihadapi. Certainty Factor berfungsi untuk mengakomodasi ketidakpastian pemikiran (inexact reasoning) seorang pakar. Certainty Factor menyatakan kepercayaan dalam sebuah kejadian (fakta atau hipotesa) berdasar bukti atau penilaian pakar [9]

Rumus dari metode Certainty Factor ditunjukkan pada persamaan 1 :

$$
\mathrm{CF}[\mathrm{H}, \mathrm{E}] 1=\mathrm{CF}[\mathrm{H}] * \mathrm{CF}[\mathrm{E}]
$$

Keterangan:

CF[H,E]: Certainty Factor dalam hipotesa (H) yang dipengaruhi Fakta (E)

H : Hipotesa atau asumsi awal terhadap gejala.

E : Evidence atau fakta dan peristiwa yang dialami user terhadap gejala

Selanjutnya adalah melakukan kombinasi nilai

CF dari masing-masing gejala. Dengan Rumus ditunjukkan pada persamaan 2 dan 3:

CF Combine $[\mathrm{H}, \mathrm{E}] 1,2=\mathrm{CF}[\mathrm{H}, \mathrm{E}] 1+\mathrm{CF}[\mathrm{H}, \mathrm{E}] 2$

* (1 - CF[H,E]1)

$\mathrm{CF}$ Combine $[\mathrm{H}, \mathrm{E}]$ old, $3=\mathrm{CF}[\mathrm{H}, \mathrm{E}]$ old + $\mathrm{CF}[\mathrm{H}, \mathrm{E}] 3 *(1-\mathrm{CF}[\mathrm{H}, \mathrm{E}]$ old $)$

Keterangan:

CF Combine [H,E]1,2 : Kombinasi dari $\mathrm{CF}[\mathrm{H}, \mathrm{E}] 1$ dan $\mathrm{CF}[\mathrm{H}, \mathrm{E}] 2$

CF Combine [H,E]old,3 :Kombinasi dari perhitungan $\mathrm{CF}[\mathrm{H}, \mathrm{E}]$ old atau $\mathrm{CF}[\mathrm{H}, \mathrm{E}] 1,2$ dengan $\mathrm{CF}[\mathrm{H}, \mathrm{E}] 3$

Perhitungan Kombinasi antar CF ini akan terus dilakukan sampai gejala yang diinputkan oleh user berakhir. Setelah melakukan kombinasi antar CF dan menemukan nilai keyakinan, berikutnya adalah mengubah nilai keyakinan menjadi presentase keyakinan. Dengan Rumus ditunjukkan pada persamaan 4:

$$
\mathrm{CF}=\mathrm{CFold} n \times 100 \%
$$

Keterangan:

CFold $\boldsymbol{n}$ : CF Combine terakhir dari kemungkinan gejala yang ada

\section{METODE PENELITIAN}

\subsection{Perancangan Sistem}

Dalam pembuatan sistem pakar diagnosis penyakit ikan koi terdapat sebuah perancangan yang meliputi Blok Diagram, Flowchart

\subsection{Blok Diagram}

Blok diagram adalah diagram dari sebuah sistem, di mana bagian utama atau fungsi yang diwakili oleh blok dihubungkan dengan garis, yang menunjukkan hubungan dari blok. proses kerja pada sistem pakar diagnosis penyakit ikan koi menggunakan metode certainty factor ditunjukan pada Gambar 2 


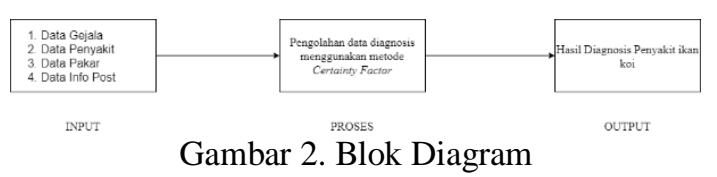

\subsection{Flowchart Metode}

Flowchart metode ini menjelaskan proses urutan sistem dari metode certainty factor seperti ditunjukkan pada gambar 3

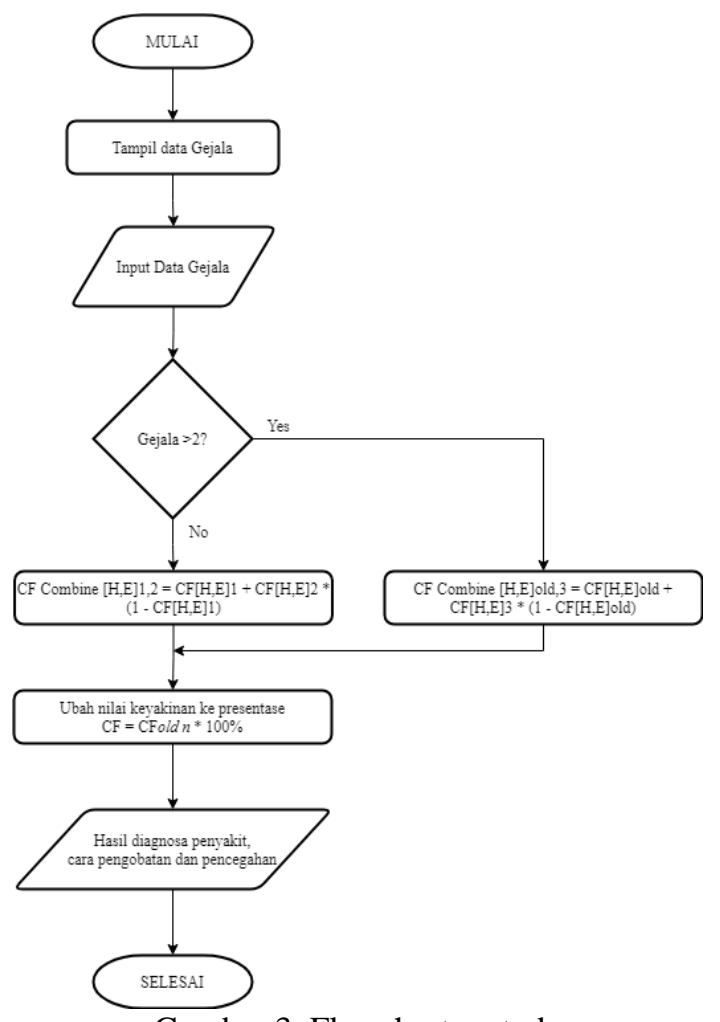

Gambar 3. Flowchart metode

Berdasarkan flowchart pada gambar 3 sistem dimulai dengan menentukan gejala yang nanti akan diinputkan. selanjutnya proses penginputan gejala sesuai dengan gejala yang muncul. Setelah gejala ditentukan dihitung ada berapa jumlah gejala, jika lebih dari 2 maka menggunakan rumus CF Combine $[\mathrm{H}, \mathrm{E}] \mathrm{old} 3$, dan jika kurang atau sama dengan 2 maka menggunakan rumus CF Combine [H,E]1,2. Setelah nilai $\mathrm{CF}$ ditemukan diubah dari nilai keyakinan ke presentase menggunakan rumus CF CFold $\mathrm{n} * 100 \%$. Proses terakhir yaitu output hasil diagnosis penyakit pada ikan koi, dan cara pengobatan

\subsection{Flowchart Admin}

Flowchart admin ini menjelaskan proses berjalannya alur aplikasi dari admin seperti ditunjukkan pada Gambar 4.

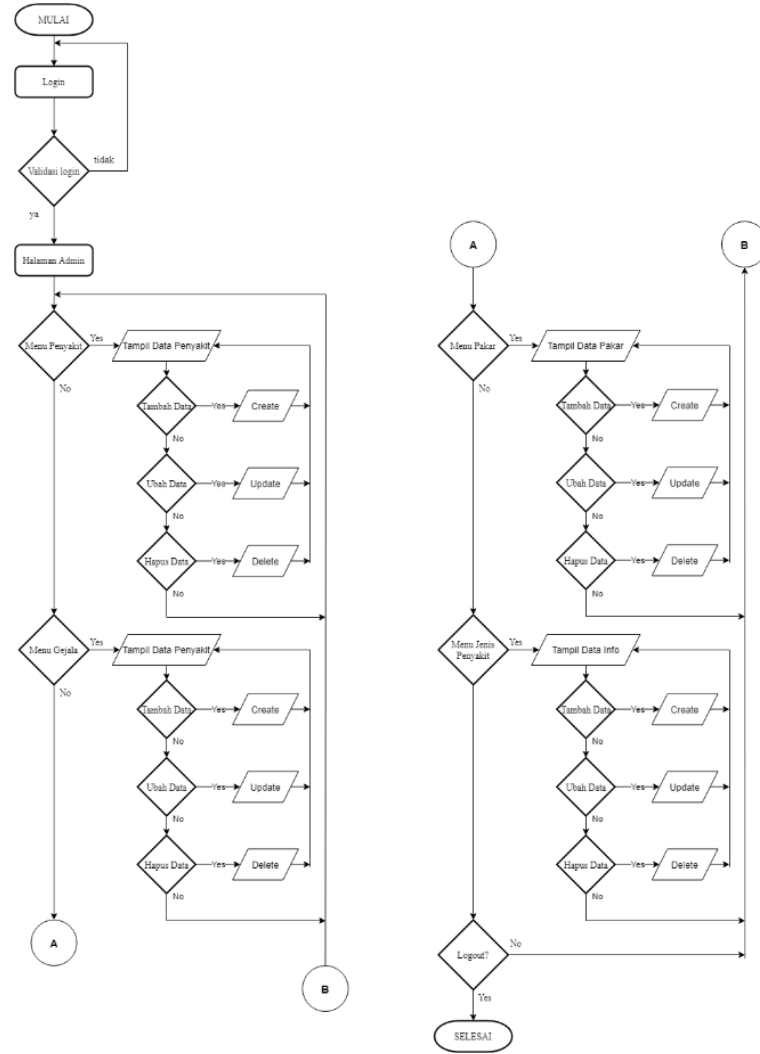

Gambar 4. Flowchart admin

Berdasarkan flowchart pada gambar 4 sistem dimulai dengan melakukan login dan akan masuk ke halaman admin, pada halaman admin terdapat beberapa menu, antara lain Menu Jenis penyakit, didalam menu jenis penyakit akan menampilkan informasi atau jenis-jenis penyakit pada ikan koi. Menu gejala, didalam menu gejala akan menampilkan data gejala sesuai masing-masing penyakit ikan. Menu penyakit, didalam menu penyakit terdapat data penyakit serta cara pengobatannya nantinya data penyakit ini akan muncul setelah proses diagnosis. Menu pakar, didalam menu pakar terdapat data penyakit dan gejala masing-masing yang sudah ditentukan nilainya oleh ahli pakar. Didalam semua menu admin terdapat fitur CRUD yang digunakan admin untuk menambah, mengedit dan menghapus data pada masing-masing menu. Menu terakhir yaitu logout jika admin memilih logout program akan selesai, jika tidak maka akan tetap pada halaman admin

\subsection{Flowchart User}

Flowchart user ini menjelaskan proses berjalannya alur aplikasi dari user seperti ditunjukkan pada Gambar 5. 


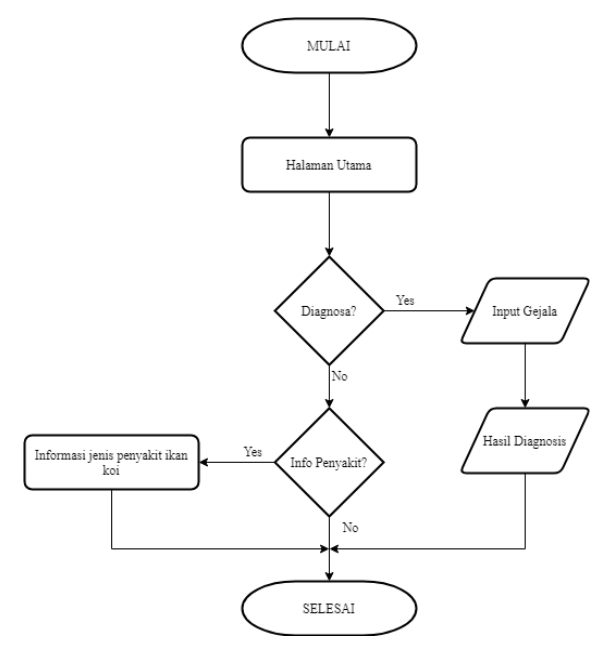

Gambar 5. Flowchart user

Flowchart user menjelaskan alur dari sistem program yang dibuat dari sisi user. Pada halaman user terdapat menu diagnosis, didalam menu diagnosis terdapat pilihan gejala yang nantinya dipilih oleh user berdasarkan gejala yang muncul pada ikan koi, setelah menginputkan gejala maka akan diproses dan menghasilkan output hasil diagnosis. Jika tidak ingin mengakses menu diagnosis user bisa ke menu lainya yaitu menu info penyakit, didalamnya terdapat informasi jenis-jenis penyakit pada ikan koi dan cara pencegahannya. di halaman user ini hanya terdapat 2 menu.

\subsection{Data Penyakit}

Tabel 1. Data penyakit

\begin{tabular}{|l|l|}
\hline ID & \multicolumn{1}{|c|}{ PENYAKIT } \\
\hline P1 & Cacing Jangkar \\
\hline P2 & Kutu Ikan \\
\hline P3 & Cloudy Eye \\
\hline P4 & White Spot \\
\hline P5 & Dropsy \\
\hline P6 & Herpes Virus \\
\hline P7 & Columnaris \\
\hline P8 & Aeromonas \\
\hline P9 & Gyrodactylus \\
\hline P10 & Chilodonella \\
\hline
\end{tabular}

Pada perancangan data penyakit dibawah menjelaskan tabel 1 adalah rancangan data penyakit yang berisi kode dan jenis penyakit yang akan diimplementasikan ke metode Certainty Factor

\subsection{Data Gejala}

Pada perancangan data gejala dibawah menjelaskan tabel 2 merupakan rancangan data gejala yang berisi kode dan macam-macam gejala yang akan diimplementasikan ke metode Certainty Factor

Tabel 2. Data gejala

\begin{tabular}{|c|l|}
\hline ID & \multicolumn{1}{|c|}{ GEJALA } \\
\hline G01 & Ikan melompat \\
\hline G02 & Berenang dengan cepat \\
\hline G03 & menggesekkan tubuh \\
\hline G04 & Megap di permukaan \\
\hline G05 & Lesu \\
\hline G06 & Parasit berbentuk jangkar di badan \\
\hline G07 & Kulit Berdarah \\
\hline G08 & Mengibaskan Sirip \\
\hline G09 & Mata Berkabut \\
\hline G10 & Mata menonjol \\
\hline G11 & Lendir berlebih \\
\hline G12 & Iritasi pada Kulit \\
\hline G13 & bintik putih di badan \\
\hline G14 & Badan membengkak \\
\hline G15 & Sisik berdiri \\
\hline G16 & Lapisan insang rusak \\
\hline G17 & Sisik terlepas \\
\hline G18 & Kulit tampak terbakar \\
\hline G19 & Bagian sekitar mulut merah \\
\hline G20 & Iritasi pada sirip \\
\hline G21 & Berkumpul di pancuran air \\
\hline G22 & Bagian kepala menjadi putih \\
\hline G23 & Lapisan insang berwarna pucat \\
\hline G24 & Parasit berbentuk bulat dibadan \\
\hline G25 & Warna kulit memudar dan pucat \\
\hline
\end{tabular}

\subsection{Rule Sistem Pakar}

Dalam Rule sistem pakar berisikan kode penyakit dan kode gejala yang dimana dalam satu kode penyakit terdapat beberapa gejala untuk membuat satu kesimpulan akhir. Setiap penyakit memiliki gejala yang berbeda maka untuk mempermudah dalam mengetahui gejala yang dialami tiap-tiap penyakit. Seperti yang ditunjukkan pada tabel 3 berikut.

Tabel 3. Rule sistem pakar

\begin{tabular}{|l|l|}
\hline R1 & IF (G01 AND G02 AND G03 AND G04 AND G05 AND G06 AND G07) THEN P1 \\
\hline R2 & IF (G01 AND G02 AND G03 AND G04 AND G05 AND G24 AND G08) THEN P2 \\
\hline R3 & IF (G09 AND G10 AND G11) THEN P3 \\
\hline R4 & IF (G02 AND G03 AND G11 AND G12 AND G13) THEN P4 \\
\hline R5 & IF (G04 AND G07 AND G14 AND G15) THEN P5 \\
\hline R6 & IF (G05 AND G07 AND G12 AND G16) THEN P6 \\
\hline R7 & IF (G03 AND G07 AND G12 AND G17) THEN P7 \\
\hline R8 & IF (G12 AND G15 AND G18 AND G19) THEN P8 \\
\hline R9 & IF (G03 AND G11 AND G16 AND G20 AND G25) THEN P9 \\
\hline R10 & IF (G11 AND G21 AND G22 AND G23) THEN P10 \\
\hline
\end{tabular}




\subsection{Nilai Pakar}

Dalam Nilai pakar berisikan nilai-nilai yang diinputkan secara langsung oleh seorang pakar, nlai dari MB dan MD dari masing-masing gejala berbeda. Dimana MB merupakan nilai keyakinan gejala muncul terhadap penyakit tersebut, sedangkan MD nilai ketidak pastian gejala tersebut muncul. untuk mempermudah dalam mengidentifikasi nilai pakar maka akan dijelaskan dalam Gambar 6

\begin{tabular}{|c|c|c|c|c|c|c|c|c|c|c|c|c|c|c|c|c|c|c|c|c|c|}
\hline & & \multicolumn{2}{|c|}{ P1 } & \multicolumn{2}{|c|}{$\mathrm{P} 2$} & \multicolumn{2}{|c|}{ P3 } & \multicolumn{2}{|c|}{ P4 } & \multicolumn{2}{|c|}{ P5 } & \multicolumn{2}{|c|}{ P6 } & \multicolumn{2}{|c|}{$\mathrm{PT}$} & \multicolumn{2}{|c|}{ P8 } & \multicolumn{2}{|c|}{ P9 } & \multicolumn{2}{|c|}{ P10 } \\
\hline & \multirow{2}{*}{ GEJALLAIPENYAKT } & \multicolumn{2}{|c|}{ Eecied, Jas.tk- } & \multicolumn{2}{|c|}{ K=t= lk=: } & \multicolumn{2}{|c|}{ Clandy Ex* } & \multicolumn{2}{|c|}{ Pbite Sput } & \multicolumn{2}{|c|}{ Drmpry } & \multicolumn{2}{|c|}{ Herves firer } & \multicolumn{2}{|c|}{ Celenaurix } & \multicolumn{2}{|c|}{ Atrmanes } & \multicolumn{2}{|c|}{ Gyradectyler } & \multicolumn{2}{|c|}{ CLil-dun+II" } \\
\hline & & ANE & $A N O$ & MNE & $A N D$ & \begin{tabular}{|l|}
$A N E$ \\
\end{tabular} & $A N D$ & \begin{tabular}{|l|}
$A N E$ \\
\end{tabular} & $M N O$ & ANE & $M N D$ & $A N E$ & $A N O$ & ANE & $A W O$ & \begin{tabular}{|l|} 
ANE \\
\end{tabular} & $M O$ & MNE & $\mid A N D$ & MNE & $A N D$ \\
\hline G01 & Melompst & 0.8 & 0 & 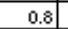 & 0 & & & & & & & & & & & & & & & & \\
\hline $\mathrm{G} 02$ & Berenong dengon cepst & 0.6 & 0 & 0.8 & 0 & & & 0.6 & 0 & & & & & & & & & & & & \\
\hline G03 & menggezekkon tubuh & 0.8 & 0 & 1 & 0 & & & 0.6 & 0 & & & & & 0.6 & 0 & & & 1 & 0 & & \\
\hline G04 & Megap di permukasn & 0.4 & 0 & 0.4 & 0 & & & & & 0.6 & 0 & & & & & & & & & & \\
\hline G05 & Leav & 0.4 & 0 & 0.4 & 0 & & & & & & & 0.8 & 0 & & & & & & & & \\
\hline G06 & Parogit berbentuk jongkor di bodon & 1 & 0 & & & & & & & & & & & & & & & & & & \\
\hline G07 & Kulit Berdarsh & 0.8 & 0 & & & & & & & 0.4 & 0 & 0.6 & 0 & 0.4 & 0 & & & & & & \\
\hline G08 & Mengibaskon Sirip & & & \begin{tabular}{l|l}
0.8 \\
\end{tabular} & 0 & & & & & & & & & & & & & & & & \\
\hline G09 & Mots Berkabut & & & & & 1 & 0 & & & & & & & & & & & & & & \\
\hline G10 & Moto menonjol & & & & & 0.6 & 0 & & & & & & & & & & & & & & \\
\hline G11 & Lendir berlebih & & & & & 0.4 & 0 & 0.4 & 0 & & & & & & & & & 0.4 & 0 & 0.4 & 0 \\
\hline G12 & Iritsei podo Kulit & & & & & & & 0.8 & 0 & & & 0.8 & 0 & 0.8 & 0 & 0.8 & 0 & & & & \\
\hline G13 & bintik putih di badon & & & & & & & 1 & 0 & & & & & & & & & & & & \\
\hline G14 & Badan membengkak & & & & & & & & & 1 & 0 & & & & & & & & & & \\
\hline G15 & Sizik berdiri & & & & & & & & & 0.8 & 0 & t & & & & 0.8 & 0 & & & & \\
\hline G16 & Lopizon insong russk & & & & & & & & & & & 1 & 0 & & & & & 0.4 & 0 & & \\
\hline G17 & Sisik terlepos & & & & & & & & & & & & & 1 & 0 & & & & & & \\
\hline G18 & Kulit tompak terbakor & & & & & & & & & & & & & & & 1 & 0 & & & & \\
\hline G19 & Bagisn zckitor mulut merah & & & & & & & & & & & & & & & 0.4 & 0 & & & & \\
\hline 520 & Iritosi pods sirip & & & & & & & & & & & & & & & & & 0.6 & 0 & & \\
\hline G21 & Berkumpul di pancuran sir & & & & & & & & & & & & & & & & & & & 0.8 & 0 \\
\hline G22 & Eogion kepsols menjadi putih & & & & & & & & & & & & & & & & & & & 0.6 & 0 \\
\hline $\mathrm{G} 23$ & Lapisan insangpucat & & & & & & & & & & & & & & & & & & & 1 & 0 \\
\hline G24 & Parasit berbentuk piring dib & & & 1 & 0 & & & & & & & & & & & & & & & & \\
\hline G25 & | warna kulit memudar dan pu & & & & & & & & & & & & & & & & & 1] & 0 & & \\
\hline
\end{tabular}

Gambar 6. Nilai pakar

\subsection{Perhitungan Certainty Factor}

Berikut merupakan contoh perhitungan manual yang prosesnya sama seperti aplikasi sistem pakar ini bekerja. Contoh kasus ikan koi dengan inputan gejala sebagai berikut:

1. Mata Berkabut (Pasti Iya)

Nilai dari pakar (MB : 1.0, MD : 0)

2. Mata menonjol (Pasti Iya)

Nilai dari pakar (MB : 0.6, MD : 0)

3. Lendir berlebih (Pasti Iya)

Nilai dari pakar (MB : $0.4, \mathrm{MD}: 0)$

1.Langkah pertama

menghitung nilai $\mathrm{CF}$ dengan mengkalikan $\mathrm{CF}$ dari pakar dan $\mathrm{CF}$ yang diinputkan oleh user.

$\mathrm{CF}[\mathrm{H}, \mathrm{E}]_{1}=\mathrm{CF}[\mathrm{H}]^{*} \mathrm{CF}[\mathrm{E}]$

$=1.0 * 1.0$

$=1.0$

$\mathrm{CF}[\mathrm{H}, \mathrm{E}]_{2}=\mathrm{CF}[\mathrm{H}] * \mathrm{CF}[\mathrm{E}]$

$=0.6 * 1.0$

$=0.6$

$\mathrm{CF}[\mathrm{H}, \mathrm{E}]_{3}=\mathrm{CF}[\mathrm{H}] * \mathrm{CF}[\mathrm{E}]$

$=0.4 * 1.0$

$=0.4$

2.Langkah Kedua

Melakukan kombinasi nilai CF dari masing-masing gejala
$\mathrm{CF}$ Combine $[\mathrm{H}, \mathrm{E}]_{1,2}=\mathrm{CF}[\mathrm{H}, \mathrm{E}]_{1}+$ $\mathrm{CF}[\mathrm{H}, \mathrm{E}]_{2} *\left(1-\mathrm{CF}[\mathrm{H}, \mathrm{E}]_{1}\right)$

$=1+0.6 *(1-1)$

$=1$

$\mathrm{CF}$ Combine $[\mathrm{H}, \mathrm{E}]_{\text {old }, 3}=\mathrm{CF}[\mathrm{H}, \mathrm{E}]_{\text {old }}+$ $\mathrm{CF}[\mathrm{H}, \mathrm{E}]_{3} *\left(1-\mathrm{CF}[\mathrm{H}, \mathrm{E}]_{\text {old }}\right)$

$=1+0.4 *(1-1)$

$=1$

3.Langkah Ketiga

Setelah diperoleh hasil akhir, maka mengubah nilai hasil akhir keyakinan menjadi presentase keyakinan.

$\mathrm{CF}=\mathrm{CFold} n \mathrm{x} 100 \%$

$=1 * 100 \%$

$=100 \%$ Cloudy Eye

Jadi gejala yang diinputkan user dengan nilai tersebut menghasilkan diagnosis penyakit berupa Cloudy eye dengan tingkat keyakinan sebesar $100 \%$

\section{HASIL DAN PEMBAHASAN}

\subsection{Halaman Diagnosa}

Pada halaman diagnosa terdapat pilihan diagnosis dan kondisi yang akan dipilih user sesuai dengan kondisi ikan koi. Tampilan halaman diagnosis dapat dilihat pada gambar 7 


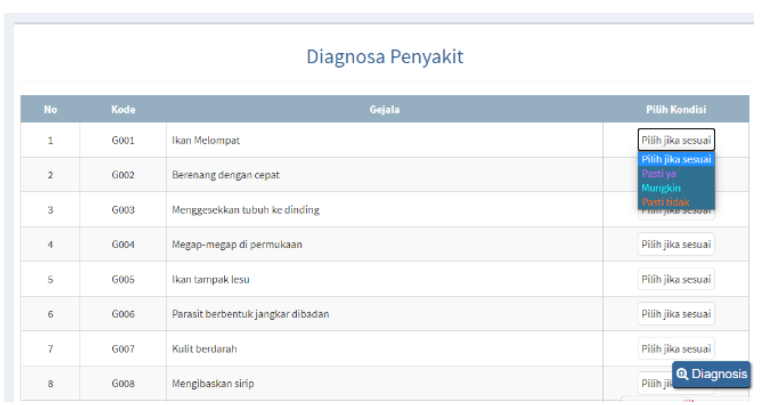

Gambar 7. Halaman diagnosa

\subsection{Halaman Post Penyakit}

Pada halaman ini menampilkan post informasi jenis-jenis penyakit ikan koi yang nantinya diakses oleh user, berisi nama penyakit, detail, dan juga saran pengobatan atau pencegahan. Tampilan halaman post penyakit dapat dilihat pada gambar 8

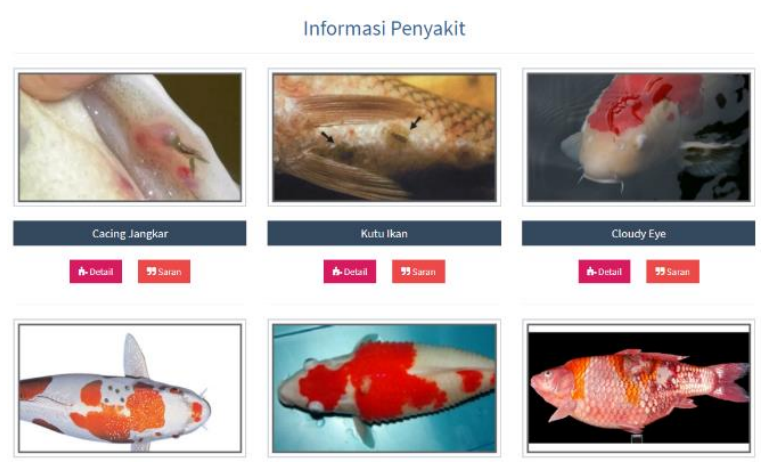

Gambar 8. Halaman post penyakit

\subsection{Halaman Data Pakar}

Halaman ini menampilkan data pakar atau basis pengetahuan, berisi nilai gejala dari masing-masing penyakit. Admin dapat melihat, menambahkan, mengubah dan juga menghapus data pakar. Tampilan halaman data pakar ditunjukkan pada gambar 9

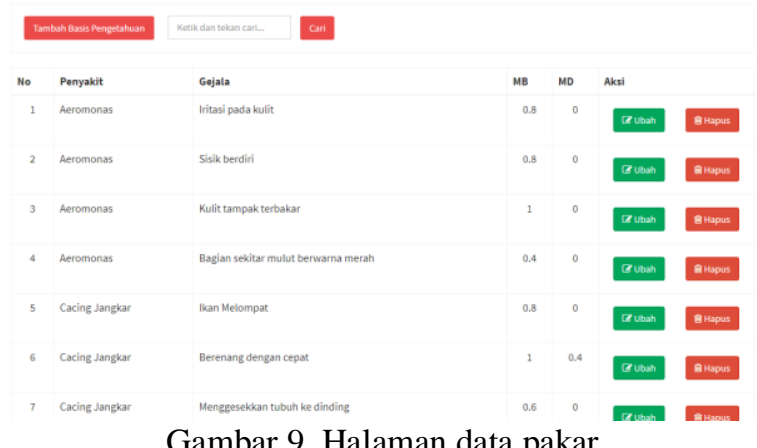

\subsection{Halaman Data Post Penyakit}

Halaman ini menampilkan data post penyakit, berisi gambar penyakit, detail, dan saran pengobatan atau pencegahan. Admin dapat melihat, menambahkan, mengubah dan juga menghapus data post penyakit. Tampilan halaman data pakar ditunjukkan pada gambar 10

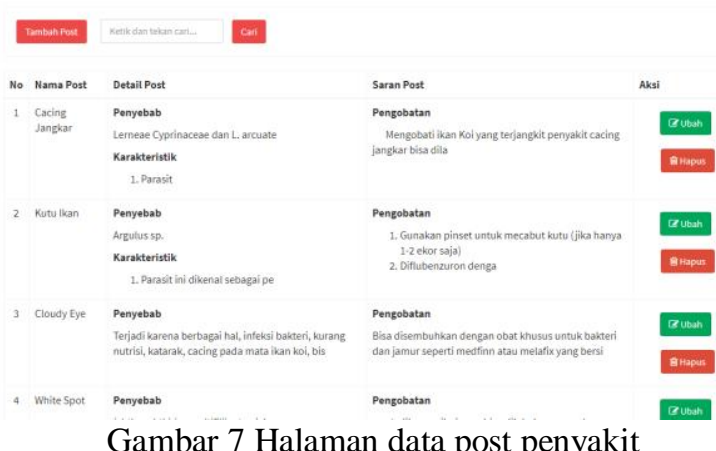

Gambar 7 Halaman data post penyakit

\subsection{Halaman Hasil Diagnosis}

Halaman ini menunjukkan hasil diagnosis dari inputan data gejala user. Menampilkan gejala apa saja yang dipilih, hasil diagnosis berupa data penyakit beserta nilai keyakinan penyakit tersebut. Tampilan halaman diagnosis ditunjukkan pada Gambar 11

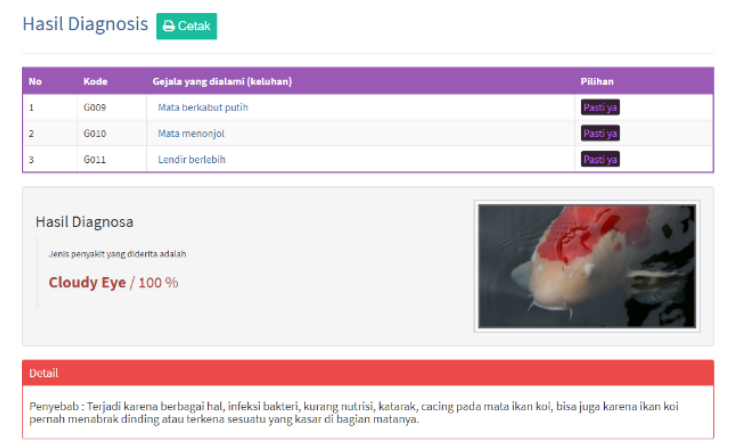

Gambar 11. Halaman hasil diagnosis

\subsection{Pengujian Fungsionalitas}

Pengujian fungsionalitas sistem dilakukan untuk menguji fitur-fitur yang ada pada sistem pakar diagnosis penyakit ikan koi berbasis web. Hasil pengujian fungsionalitas sistem ditunjukkan pada tabel 4

Tabel 4. Pengujian fungsionalitas

\begin{tabular}{|l|c|c|}
\hline \multirow{2}{*}{ Fungsi } & \multicolumn{2}{|c|}{ Browser } \\
\cline { 2 - 3 } & $\begin{array}{c}\text { Microsoft } \\
\text { Edge }\end{array}$ & $\begin{array}{c}\text { Google } \\
\text { Chrome }\end{array}$ \\
\hline Halaman Diagnosis & $\sqrt{ }$ & $\sqrt{ }$ \\
\hline Halaman Post Penyakit & $\sqrt{ }$ & $\sqrt{ }$ \\
\hline Halaman Login & $\sqrt{ }$ & $\sqrt{ }$ \\
\hline Halaman Dashboard & $\sqrt{ }$ & $\sqrt{ }$ \\
\hline Halaman data admin & $\sqrt{ }$ & $\sqrt{ }$ \\
\hline Halaman CRUD data admin & $\sqrt{ }$ & $\sqrt{ }$ \\
\hline Halaman data penyakit & $\sqrt{ }$ & $\sqrt{ }$ \\
\hline Halaman CRUD data penyakit & $\sqrt{ }$ & $\sqrt{ }$ \\
\hline Halaman data gejala & $\sqrt{ }$ & $\sqrt{ }$ \\
\hline Halaman CRUD data gejala & $\sqrt{ }$ & $\sqrt{ }$ \\
\hline Halaman data pakar & $\sqrt{ }$ & $\sqrt{ }$ \\
\hline Halaman CRUD data pakar & $\sqrt{ }$ & $\sqrt{ }$ \\
\hline Halaman data Post penyakit & $\sqrt{ }$ & $\sqrt{ }$ \\
\hline Halaman CRUD data Post & & \\
Penyakit & & \\
\hline Halaman Hasil Diagnosis & & \\
\hline Logout & &
\end{tabular}

Keterangan :

$\sqrt{ }=$ Berjalan

$\mathrm{x}=$ Tidak berjalan 


\subsection{Pengujian User}

Pengujian user ini dibagi menjadi dua yaitu pengujian user dari tampilan pengguna dan dari tampilan admin. Pengujian ini dilakukan dengan mengisi kuesioner yang diisi oleh 11 responden.

\subsection{Pengujian User (Tampilan Pengguna)}

Pengujian Tampilan pengguna dilakukan untuk melihat kelayakan dari aplikasi yang telah dibuat. Hasil dari pengujian tampilan pengguna dapat dilihat pada tabel 5

Tabel 5. Pengujian Tampilan Pengguna

\begin{tabular}{|c|c|c|c|c|c|}
\hline \multirow[b]{2}{*}{ No } & \multirow[b]{2}{*}{ Pernyataan } & \multicolumn{4}{|c|}{ Jawaban } \\
\hline & & $\begin{array}{l}\text { Sangat } \\
\text { Setuju }\end{array}$ & Setuju & $\begin{array}{c}\text { Kurang } \\
\text { Setuju }\end{array}$ & $\begin{array}{l}\text { Tidak } \\
\text { Setuju }\end{array}$ \\
\hline 1 & $\begin{array}{l}\text { Apakah tampilan } \\
\text { aplikasi website } \\
\text { sudah terlihat jelas } \\
\text { dan sesuai? }\end{array}$ & 5 & 6 & 0 & 0 \\
\hline 2 & $\begin{array}{l}\text { Apakah informasi } \\
\text { yang disediakan } \\
\text { oleh website mudah } \\
\text { dipahami? }\end{array}$ & 3 & 8 & 0 & 0 \\
\hline 3 & $\begin{array}{l}\text { Apakah aplikasi } \\
\text { website ini } \\
\text { bermanfaat untuk } \\
\text { pengguna? }\end{array}$ & 4 & 7 & 0 & 0 \\
\hline 4 & $\begin{array}{l}\text { Apakah aplikasi } \\
\text { website mempunyai } \\
\text { kemampuan dan } \\
\text { fungsi sesuai yang } \\
\text { diharapkan? }\end{array}$ & 1 & 9 & 1 & 0 \\
\hline 5 & $\begin{array}{l}\text { Apakah aplikasi } \\
\text { website ini } \\
\text { memudahkan untuk } \\
\text { mendiagnosis } \\
\text { penyakit ikan koi? }\end{array}$ & 4 & 7 & 0 & 0 \\
\hline & Total & 17 & 37 & 1 & 0 \\
\hline & Persentase & $30,91 \%$ & $67,27 \%$ & $1,82 \%$ & $0 \%$ \\
\hline
\end{tabular}

Berdasarkan Tabel 5 diketahui bahwa mayoritas user menilai pengujian tampilan pengguna dengan pernyataan setuju. Oleh karena itu aplikasi website sistem pakar diagnosis penyakit ikan koi sesuai dengan harapan user dan dapat digunakan untuk melakukan diagnosis penyakit ikan koi

\subsection{Pengujian User (Tampilan Admin)}

Pengujian tampilan admin dilakukan untuk melihat kelayakan aplikasi yang dibuat. Hasil dari pengujian tampilan admin dapat dilihat pada tabel 6

Tabel 6. Pengujian tampilan admin

\begin{tabular}{|c|l|c|c|c|c|}
\hline \multirow{2}{*}{ No } & \multicolumn{1}{|c|}{ Pernyataan } & $\begin{array}{c}\text { Sangat } \\
\text { Setuju }\end{array}$ & Setuju & $\begin{array}{c}\text { Kurang } \\
\text { Setuju }\end{array}$ & $\begin{array}{c}\text { Tidak } \\
\text { Setuju }\end{array}$ \\
\hline \multirow{2}{*}{2} & $\begin{array}{l}\text { Apakah tampilan } \\
\text { aplikasi website sudah } \\
\text { terlihat jelas dan } \\
\text { sesuai? }\end{array}$ & 0 & 1 & 0 & 0 \\
\hline & $\begin{array}{l}\text { Apakah informasi } \\
\text { yang disediakan oleh } \\
\text { website mudah } \\
\text { dipahami? }\end{array}$ & 0 & 1 & 0 & 0 \\
\hline 3 & $\begin{array}{l}\text { Apakah aplikasi } \\
\text { website sesuai } \\
\text { kebutuhan? }\end{array}$ & 1 & 0 & 0 & 0 \\
\hline
\end{tabular}

\begin{tabular}{|c|l|c|c|c|c|}
\hline 4 & $\begin{array}{l}\text { Apakah aplikasi } \\
\text { website mempunyai } \\
\text { kemampuan dan } \\
\text { fungsi sesuai yang } \\
\text { diharapkan }\end{array}$ & 1 & 0 & 0 & 0 \\
\hline 5 & $\begin{array}{l}\text { Apakah fitur aplikasi } \\
\text { website ini mudah } \\
\text { dipahami? }\end{array}$ & 0 & 0 & 1 & 0 \\
\hline Total & 2 & 2 & 1 & 0 \\
\hline Persentase & $40 \%$ & $40 \%$ & $20 \%$ & $0 \%$ \\
\hline
\end{tabular}

Berdasarkan tabel 6 diketahui bahwa user menilai pengujian tampilan admin dengan imbang di jawaban sangat setuju dan setuju dengan presentase $40 \%$. dan $20 \%$ pada jawaban kurang setuju.

\subsection{Perhitungan Sistem dengan Perhitungan Manual}

Pengujian perhitungan dilakukan untuk mengetahui ketepatan antara perhitungan sistem dengan perhitungan manual pada penyakit ikan koi sesuai dengan gejala dan kondisi yang dipilih. Pengujian perhitungan dapat dilihat pada tabel 7

Tabel 7. Perhitungan sistem dan manual

\begin{tabular}{|c|c|c|c|c|}
\hline No & Gejala & Kondisi & Sistem & Manual \\
\hline \multirow{7}{*}{1} & Melompat & Mungkin & \multirow{7}{*}{$\begin{array}{c}100 \% \\
\text { Cacing } \\
\text { Jangka } \\
\text { r }\end{array}$} & \multirow{7}{*}{$\begin{array}{c}100 \% \\
\text { Cacing } \\
\text { Jangkar }\end{array}$} \\
\hline & $\begin{array}{l}\text { Berenang dengan } \\
\text { cepat }\end{array}$ & Pasti Iya & & \\
\hline & $\begin{array}{l}\text { menggesekkan } \\
\text { tubuh }\end{array}$ & Mungkin & & \\
\hline & $\begin{array}{l}\text { Megap di } \\
\text { permukaan }\end{array}$ & Pasti Iya & & \\
\hline & Lesu & Pasti Iya & & \\
\hline & $\begin{array}{l}\text { Parasit tampak di } \\
\text { badan }\end{array}$ & Pasti Iya & & \\
\hline & Kulit Berdarah & Mungkin & & \\
\hline \multirow{7}{*}{2} & Melompat & Mungkin & \multirow{7}{*}{$\begin{array}{l}96 \% \\
\text { Kutu } \\
\text { Ikan }\end{array}$} & \multirow{7}{*}{$\begin{array}{l}96 \% \\
\text { Kutu } \\
\text { Ikan }\end{array}$} \\
\hline & $\begin{array}{l}\text { Berenang dengan } \\
\text { cepat }\end{array}$ & Mungkin & & \\
\hline & $\begin{array}{l}\text { menggesekkan } \\
\text { tubuh }\end{array}$ & $\begin{array}{l}\text { Pasti } \\
\text { Tidak } \\
\end{array}$ & & \\
\hline & $\begin{array}{l}\text { Megap di } \\
\text { permukaan }\end{array}$ & Pasti Iya & & \\
\hline & Lesu & Pasti Iya & & \\
\hline & $\begin{array}{l}\text { Parasit tampak di } \\
\text { badan }\end{array}$ & Mungkin & & \\
\hline & Mengibaskan Sirip & Pasti Iya & & \\
\hline \multirow{3}{*}{3} & Mata Berkabut & Pasti Iya & \multirow{4}{*}{$\begin{array}{c}100 \% \\
\text { Cloudy } \\
\text { Eye }\end{array}$} & \multirow{4}{*}{$\begin{array}{c}100 \% \\
\text { Cloudy } \\
\text { Eye }\end{array}$} \\
\hline & Mata menonjol & Mungkin & & \\
\hline & Lendir berlebih & Pasti Iya & & \\
\hline \multirow{5}{*}{4} & $\begin{array}{l}\text { Berenang dengan } \\
\text { cepat }\end{array}$ & Mungkin & & \\
\hline & $\begin{array}{l}\text { menggesekkan } \\
\text { tubuh }\end{array}$ & $\begin{array}{l}\text { Pasti } \\
\text { Tidak } \\
\end{array}$ & \multirow{4}{*}{$\begin{array}{l}97 \% \\
\text { White } \\
\text { Spot }\end{array}$} & \multirow{4}{*}{$\begin{array}{l}97 \% \\
\text { White } \\
\text { Spot }\end{array}$} \\
\hline & Lendir berlebih & Pasti Iya & & \\
\hline & Iritasi pada Kulit & Mungkin & & \\
\hline & $\begin{array}{l}\text { bintik putih di } \\
\text { badan }\end{array}$ & Pasti Iya & & \\
\hline \multirow{4}{*}{5} & $\begin{array}{l}\text { Megap di } \\
\text { permukaan }\end{array}$ & Mungkin & \multirow{4}{*}{$\begin{array}{l}92 \% \\
\text { Dropsy }\end{array}$} & \multirow{4}{*}{$\begin{array}{l}92 \% \\
\text { Dropsy }\end{array}$} \\
\hline & Kulit Berdarah & Mungkin & & \\
\hline & $\begin{array}{l}\text { Badan } \\
\text { membengkak }\end{array}$ & Mungkin & & \\
\hline & Sisik berdiri & Pasti Iya & & \\
\hline \multirow{4}{*}{6} & Lesu & Pasti Iya & \multirow{4}{*}{$\begin{array}{c}100 \% \\
\text { Herpes } \\
\text { Virus }\end{array}$} & \multirow{4}{*}{$\begin{array}{c}100 \% \\
\text { Herpes } \\
\text { Virus }\end{array}$} \\
\hline & Kulit Berdarah & Mungkin & & \\
\hline & Iritasi pada Kulit & Mungkin & & \\
\hline & $\begin{array}{l}\text { Lapisan insang } \\
\text { rusak }\end{array}$ & Pasti Iya & & \\
\hline
\end{tabular}




\begin{tabular}{|c|c|c|c|c|}
\hline No & Gejala & Kondisi & Sistem & Manual \\
\hline \multirow{4}{*}{7} & $\begin{array}{l}\text { menggesekkan } \\
\text { tubuh }\end{array}$ & Mungkin & \multirow{4}{*}{$\begin{array}{c}100 \% \\
\text { Colum } \\
\text { naris }\end{array}$} & \multirow{4}{*}{$\begin{array}{c}100 \% \\
\text { Column } \\
\text { aris }\end{array}$} \\
\hline & Kulit Berdarah & Pasti Iya & & \\
\hline & Iritasi pada Kulit & Mungkin & & \\
\hline & Sisik terlepas & Pasti Iya & & \\
\hline \multirow{4}{*}{8} & Iritasi pada Kulit & Mungkin & \multirow{4}{*}{$\begin{array}{c}100 \% \\
\text { Aerom } \\
\text { onas }\end{array}$} & \multirow{4}{*}{$\begin{array}{c}100 \% \\
\text { Aeromo } \\
\text { nas }\end{array}$} \\
\hline & Sisik berdiri & Mungkin & & \\
\hline & $\begin{array}{l}\text { Kulit tampak } \\
\text { terbakar }\end{array}$ & Pasti Iya & & \\
\hline & $\begin{array}{l}\text { Bagian sekitar } \\
\text { mulut merah }\end{array}$ & Mungkin & & \\
\hline \multirow{4}{*}{9} & $\begin{array}{l}\text { menggesekkan } \\
\text { tubuh }\end{array}$ & Pasti Iya & \multirow{4}{*}{$\begin{array}{l}100 \% \\
\text { Gyrod } \\
\text { actillus }\end{array}$} & \multirow{4}{*}{$\begin{array}{c}100 \% \\
\text { Gyroda } \\
\text { ctillus }\end{array}$} \\
\hline & Lendir berlebih & Mungkin & & \\
\hline & $\begin{array}{l}\text { Lapisan insang } \\
\text { rusak }\end{array}$ & Mungkin & & \\
\hline & Iritasi pada sirip & Pasti Iya & & \\
\hline \multirow{4}{*}{10} & Lendir berlebih & Mungkin & \multirow{4}{*}{$\begin{array}{l}100 \% \\
\text { Chilod } \\
\text { onella }\end{array}$} & \multirow{4}{*}{$\begin{array}{c}100 \% \\
\text { Chilodo } \\
\text { nella }\end{array}$} \\
\hline & $\begin{array}{l}\text { Berkumpul di } \\
\text { pancuran air }\end{array}$ & Pasti Iya & & \\
\hline & $\begin{array}{l}\text { Bagian kepala } \\
\text { menjadi putih }\end{array}$ & Pasti Iya & & \\
\hline & $\begin{array}{l}\text { Lapisan insang } \\
\text { pucat }\end{array}$ & Pasti Iya & & \\
\hline
\end{tabular}

Berdasarkan tabel 7 dapat dilihat 10 inputan dengan gejala random, pengujian perhitungan sistem dan manual mendapatkan presentase ketepatan $100 \%$ karena output berupa 10 hasil tepat

\subsection{Diagnosis Sistem dengan Diagnosis Pakar}

Pengujian dilakukan untuk mengetahui ketepatan hasil diagnosis oleh sistem dengan hasil diagnosis yang diberikan oleh pakar secara langsung. Pengujian diagnosis ditunjukkan pada tabel 8

Tabel 8. Diagnosis sitem dan pakar

\begin{tabular}{|c|l|c|c|}
\hline No & Penyakit & $\begin{array}{c}\text { Diagnosis } \\
\text { tepat }\end{array}$ & $\begin{array}{c}\text { Diagnosis } \\
\text { tidak } \\
\text { tepat }\end{array}$ \\
\hline 1 & Cacing jangkar & 5 & 0 \\
\hline 2 & Kutu Ikan & 5 & 0 \\
\hline 3 & Cloudy Eye & 5 & 0 \\
\hline 4 & White spot & 5 & 0 \\
\hline 5 & Dropsy & 5 & 0 \\
\hline 6 & Herpes Virus & 4 & 1 \\
\hline 7 & Columnaris & 5 & 0 \\
\hline 8 & Aeromonas & 5 & 0 \\
\hline 9 & Gyrodactillus & 4 & 1 \\
\hline 10 & Chilodonella & 3 & 2 \\
\hline
\end{tabular}

Berdasarkan tabel 8 dapat dilihat untuk penyakit "Cacing jangkar, kutu ikan, cloudy eye, white spot, dropsy, columnaris, aeromonas" dari 5 kali pengujian, semua diagnosis tepat. Untuk penyakit "Herpes virus dan gyrodactillus" dari 5 kali pengujian diagnosis tepat 4 dan diagnosis tidak tepat 1 . Sedangkan penyakit "Chilodonella" dari 5 kali pengujian diagnosis tepat 3 dan diagnosis tidak tepat 2. Diperoleh total hasil tepat 46, dan total hasil tidak tepat 4. presentase hasil diagnosis tepat $46 / 50 * 100=92 \%$, presentase hasil tidak tepat $4 / 50 * 100=$ $8 \%$. maka dari itu pengujian diagnosis sistem dan pakar mendapatkan tingkat keakurasian sebesar $92 \%$

\section{KESIMPULAN DAN SARAN}

\subsection{Kesimpulan}

Kesimpulan yang dapat penulis paparkan setelah melakukan pembuatan sistem pakar diagnosis penyakit ikan koi dengan menggunakan metode certainty factor, yaitu:

1. Berdasarkan hasil pengujian fungsionalitas pada aplikasi sistem pakar dapat dijalankan dengan baik pada browser web Microsoft Edge dan Google Chrome berjalan 100\%.

2. Aplikasi sistem pakar diagnosis penyakit ikan koi berbasis web ini berhasil melakukan diagnosis sesuai dengan metode yang diimplementasikan, yaitu Certainty Factor dan sesuai dengan hasil diagnosis pakar dengan nilai sebesar $92 \%$

\subsection{Saran}

Untuk pengembangan aplikasi yang lebih baik, ada beberapa saran pada aplikasi sistem pakar diagnosis penyakit ikan koi menggunakan metode certainty factor berbasis web yaitu:

1. Penelitian selanjutnya bisa menggunakan mesin inferensi lain, yaitu backward chaining.

2. Penelitian selanjutnya dapat menambahkan data gejala dan data penyakit yang lebih lengkap

3. Penelitian selanjutnya sistem pakar diagnosis penyakit ikan koi dapat dikembangkan dengan berbasis mobile

\section{DAFTAR PUSTAKA}

[1] M. Efendi dan U. M. Papilon, Ikan Koi, Cibubur, Jakarta Timur: Penebar Swadaya, 2017.

[2] W. Mariana, "SISTEM PAKAR DIAGNOSIS PENYAKIT TANAMAN SEMANGKA MENGGUNAKAN METODE CERTAINTY FACTOR," JATI (Jurnal Mahasiswa Teknik Informatika) Vol. 3 No. 1, pp. 24-30, 2019

[3] M. M. A. Saputra, "SISTEM PAKAR DIAGNOSIS PENYAKIT PENCERNAAN PADA MANUSIA MENGGUNAKAN METODE CERTAINTY FACTOR," JATI (Jurnal Mahasiswa Teknik Informatika) Vol. 3 No. 1, pp. 181-188, 2019

[4] Sinaga, P. M. Hasugian dan A. M. Manurung, "SISTEM PAKAR MENDIAGNOSA KERUSAKANSMARTPHONE ANDROID MENGGUNAKAN METODE CERTAINTY FACTOR," Journal Of Informatic Pelita Nusantara Volume 3 No 1 e-ISSN 2541-3724, pp. 56-62, 2018

[5] L. F. Putri, "Perancangan Aplikasi Sistem Pakar Penyakit Roseola Dengan Menggunakan Metode Certainty Factor," Jurnal Sistem Komputer dan Informatika, Vol. 1, No. 2, pp. 107-113, 2020

[6] P. Wahyuningsih dan S. Zuhriyah, "SISTEM PAKAR DIAGNOSA PENYAKIT CAMPAK RUBELLA PADA ANAK MENGGUNAKAN 
METODE CERTAINTY FACTOR BERBASIS

WEBSITE," Jurnal Teknologi Informasi dan

Ilmu Komputer (JTIIK) DOI:

10.25126/jtiik.202182710 Vol. 8, No. 1, pp. 8594, 2021

[7] Pendidikan, "Sistem Pakar," 26 April 2021. [Online]. Available: https://www.dosenpendidikan.co.id/sistempakar/.

[8] T. Hariyati dan L. Kurnia, "SISTEM PAKARMENDIAGNOSA PENYAKIT UMUM YANG SERING DIDERITABALITA BERBASIS WEB DI DINAS KESEHATAN KOTA BANDUNG," Jurnal Komputer dan Informatika (KOMPUTA) Edisi. I Volume. 1, pp. 65-69, 2012

[9] Pakpahan, J. R. Sagala dan R. Yesputra, "Implementation of Certainty Factor Method for Diagnoses of Photocopy Machine Damage," Journal of physics: Conf. Series 1225, 2019 